\title{
Troponinanalyser skjerper krav til klinisk skjønn
}

Erkjennelsen av hjertespesifikke troponiners høye sensitivitet og spesifisitet for myokardskade var en viktig foranledning til at en ekspertkomité nedsatt av European Society of Cardiology og American College of Cardiology i år 2000 utformet nye retningslinjer og kriterier for diagnostikk av akutt hjerteinfarkt. En endring i nivået av sirkulerende biokjemiske myokardskademarkører er, med visse unntak (plutselig hjertedød og påvisning av infarkt ved autopsi), et krav til diagnosen. Troponinmålinger spiller en sentral rolle i den indremedisinske hverdag i Norge. Allikevel avdekker Aakre og medarbeidere i dette nummer av Tidsskriftet betydelige ulikheter mellom sykehus med henblikk på beslutningsgrenser for diagnosen akutt hjerteinfarkt, i tillegg til ulike rutiner for tolking, kvalitetssikring og rapportering av troponinresultater (1). Disse ulikhetene medfører at en pasient med iskemisuspekte brystsmerter og en gitt troponinverdi vil kunne bli diagnostisert med akutt hjerteinfarkt ved ett sykehus, men få diagnosen ustabil angina pectoris ved et annet. Selv om ustabil angina pectoris og et hjerteinfarkt uten heving av ST-segmentet på EKG skyldes samme patofysiologiske prosess og i prinsippet medfører samme behandling, vil en troponinverdi over beslutningsgrensen for hjerteinfarkt plassere pasienten i et høyere risikostratum og således kunne virke inn på behandlingsintensitet og prioritet for henvisning til invasiv koronarutredning. Diagnosen hjerteinfarkt vil også av mange pasienter oppleves som betydelig mer alvorlig enn diagnosen angina pectoris.

Innføringen av nye, mer sensitive troponinanalyser er et diagnostisk fremskritt. To store, uavhengige undersøkelser dokumenterer at høysensitive metoder for både troponin I og troponin T øker den totale diagnostiske presisjon for akutt hjerteinfarkt sammenliknet med tidligere metoder $(2,3)$. Spesielt øker sensitiviteten betydelig hos pasienter med kort sykehistorie, noe som er viktig fordi en relativt lav sensitivitet ved innleggelsestidspunktet tidligere har vært oppfattet som den største svakheten ved troponinmålinger. Paradoksalt nok kan innføringen av mer sensitive og nøyaktige målemetoder føre til at tolking av troponinresultater blir mer krevende. Mens de tidligere, mindre sensitive versjoner av mange klinikere nærmest ble oppfattet som kvalitative tester («troponin positiv versus troponin negativ»), vil de nye analysene og de lavere beslutningsgrensene føre til at den kliniske konteksten blir viktigere for tolkingen. Spesielt vil det være av betydning å legge vekt på iskemisymptomer og elektrokardiografiske eller bildediagnostiske tegn på infarkt og å kjenne til andre årsaker til troponinstigning enn akutt koronarsyndrom.

Lettgradig troponinstigning ses ved en rekke tilstander, bl.a. nyresvikt, sepsis, kronisk obstruktiv lungesykdom, lungeembolisme, myokarditt, hjertesvikt og stabil koronarsykdom. I tillegg øker troponinverdiene med alderen og er høyere hos menn enn hos kvinner. Lett forhøyede troponinverdier hos pasienter uten klare symptomer eller andre tilleggskriterier for hjerteinfarkt må derfor ikke uten videre tolkes som tegn på akutt okklusjon av en koronararterie. I tvilstilfeller vil seriemåling av troponinnivå derfor bli viktig for å se om et lett økt nivå er stabilt eller om det etterfølges av et fall. Faren for en falskt positiv hjerteinfarktdiagnose er imidlertid ikke knyttet til manglende vesspesifisitet eller analytiske feilkilder ved troponinmåling. Det er altså ikke tale om et falskt positivt troponinsvar, men at troponinfrigjøring er assosiert med mange ulike former for myokardskade. Resultatene til Aakre og medarbeidere dokumenterer at det er behov for en standardisering sykehusene imellom når det gjelder troponinmålinger og beslutningsgrenser. Det er derfor fortjenestfullt at Norsk selskap for medisinsk biokjemi har utarbeidet nasjonale anbefalinger for implementering av nye, sensitive troponinanalyser.

Imidlertid følger ikke de nye norske anbefalingene internasjonale retningslinjer, hvor beslutningsgrensen for akutt hjerteinfarkt er gitt som 99-prosentilen i en referansepopulasjon (4). For den nye, høysensitive troponin T-metoden har man funnet en 99-prosentil på $0,014 \mu \mathrm{g} / \mathrm{l}(\mathrm{dvs} .14 \mathrm{ng} / \mathrm{l})$. Skulle man ta konsekvensen av dette, burde man i de norske anbefalingene ha valgt en beslutningsgrense for troponin T på $14 \mathrm{ng} / \mathrm{l}$. I stedet har man valgt å bruke den tidligere anbefalte grensen, $30 \mathrm{ng} / \mathrm{l}$, selv om det pga. manglende kalibrering med den tidligere troponin T-analysen ikke er direkte samsvar mellom nye og gamle verdier. Valget begrunnes med at nytteverdien av å senke grensen ennå ikke er dokumentert. Imidlertid er $14 \mathrm{ng} / \mathrm{l}$-grensen brukt som referansestandard i den største kliniske evalueringsstudien som til nå foreligger (3).

De nye norske anbefalingene angir videre at $10 \mathrm{ng} / \mathrm{ml}$ er den laveste grensen som skal angis som svar fra laboratoriet, selv om deteksjonsgrensen for den høysensitive troponin T-metoden er så lav som $2 \mathrm{ng} / \mathrm{l}$. Begrunnelsen er dels manglende analytisk presisjon, dels at betydningen av så lave troponin T-verdier har vært ukjent. Imidlertid tyder nye data på at verdier i dette konsentrasjonsområdet også gir verdifull prognostisk informasjon. I en nylig publisert studie er det klart vist at troponin T-verdier lavere enn deteksjonsgrensen til fjerdegenerasjonsmetoden gir sterk prognostisk informasjon hos pasienter med stabil koronarsykdom uten hjerte- eller nyresvikt (5).

I Norge var vi i internasjonal sammenheng tidlig ute med å implementere den nye høysensitive troponin T-analysen, og det forelå kun begrensede kliniske data da Norsk selskap for medisinsk biokjemis anbefalinger ble skrevet. Forskningsfeltet er imidlertid i rivende utvikling. Derfor er det nødvendig at slike anbefalinger revideres hyppig, slik at de i størst mulig grad er i samsvar med den til enhver tid tilgjengelige vitenskapelige dokumentasjon.

\section{Torbjørn Omland}

torbjorn.omland@medisin.uio.no

Torbjørn Omland (f. 1962) er professor I i indremedisin ved Universitetet i Oslo samt overlege ved Medisinsk divisjon, Akershus universitetssykehus.

\footnotetext{
Litteratur

1. Aakre KM, Landaas S, Hagve TA. Bruk av troponinmålinger i norske sykehus. Tidsskr Nor Legeforen 2010; 130: 278-81.

2. Keller T, Zeller T, Peetz D et al. Sensitive troponin I assay in early diagnosis of acute myocardial infarction. N Engl J Med 2009: 361: 868-77.

3. Reichlin T, Hochholzer W, Bassetti S et al. Early diagnosis of myocardial infarc tion with sensitive cardiac troponin assays. N Engl J Med 2009; 361: 858-67.

4. Thygesen K, Alpert JS, White HD. Universal definition of myocardial infarction. Eur Heart J 2007: 28: 2525-38.

5. Omland T, de Lemos JA, Sabatine MS et al. A sensitive cardiac troponin T assay in stable coronary artery disease. N Engl J Med 2009; 361: 2538-47.
} 